\section{Environmental sustainability and human well-being indicators from the ecosystem perspective in the Middle Paraíba Region, Rio de Janeiro State, Brazil}

\author{
Indicadores de sustentabilidade ambiental e \\ de bem-estar em perspectiva ecossistêmica na \\ Região do Médio Paraíba, Rio de Janeiro, Brasil
}

Carlos Machado de Freitas 1

Gabriel Eduardo Schütz ${ }^{1}$

Simone Gomes de Oliveira 1

\footnotetext{
1 Escola Nacional de Saúde Pública Sergio Arouca, Fundação Oswaldo Cruz, Rio de Janeiro, Brasil.

Correspondence C. M. Freitas Centro de Estudos da Saúde do Trabalhador e Ecologia Humana, Escola Nacional de Saúde Pública Sergio Arouca, Fundação Oswaldo Cruz. Rua Leopoldo Bulhões 1480, Rio de Janeiro, $R J$ 21041-210, Brasil. carlosmf@ensp.fiocruz.br
}

\begin{abstract}
Population urbanization is a global trend, and socioeconomic activities in urban areas cause changes that affect the environment and human well-being beyond the specific territories, thus connecting urban to non-urban areas and creating city-regions. This article's objective, from an ecosystem perspective, is to gather a set of information on municipalities (counties) belonging to the Middle Paraíba River Valley Region in the State of Rio de Janeiro, Brazil, in order to identify conditions and trends in environmental sustainability and well-being. The conceptual framework adopted here was that of the Millennium Ecosystem Assessment, identifying direct and indirect driving forces that affect human wellbeing, with health as a component of the latter. We used a set of available public-domain data and information sources on the municipalities, grouped by socioeconomic and environmental conditions and the soundness of institutional structural well-being for sustainability. The indicators used here point to a process of degradation in the ecosystem services that has still not been prevented by the prevailing institutional structure, thus increasing constraints on well-being and the spread of socio-environmental impacts in the middle and long terms.
\end{abstract}

Environmental Indicators; Health Indicators; Sustainable Development Indicators

\section{Introduction}

The changes that occurred in land ecosystems beginning with the Industrial Revolution are part of the economic growth logic that intensified in the latter half of the $20^{\text {th }}$ century, consolidating the transition to an industrial and urbanized society. The global urban population grew from 200 million in 1900 to 2.9 billion in 2000 (nearly $50 \%$ of the world population), and in regions like North America, Europe, and Latin America and the Caribbean the urban population is already more than $70 \%$ of the total 1,2 .

This process involves human migratory flows to urban areas in search of work and better living conditions. These areas, vital to industrialization and economic growth, spawned the availability of cheap labor, scale economies, and shared use of resources, infrastructure, and opportunities for production and commercialization. Meanwhile, they produced huge impacts on local, regional, and global ecosystem services, both through the growing demand for natural resources and energy and the capacity to generate waste and pollution.

Activities in urban areas lead to environmental damage that extends beyond their territories, connecting them to non-urban areas, thereby constituting city-regions 3 . As noted by Pickett et al. 4, urban sprawl not only converts the areas traditionally studied by ecological approaches into systems that require a clear appreciation of 
the role of humans; spreading urbanization itself is also among the greatest global impacts caused by humans.

Given this situation, one of the challenges for Public Health is to build systems of indicators that allow analyses of current conditions and future trends, which point to the progressive degradation of ecosystems services that support life, health, and human well-being. The indicators simplify the complexity of a set of available data and information and more clearly and directly expose to managers and the general public the problems related to sustainability, as well as the direct and indirect driving forces at their origin, thus contributing to the formulation, implementation, and monitoring of planning and management strategies 5 .

The objective of this article, from an ecosystem perspective, is to gather a set of public-access information on the municipalities (counties) belonging to the Middle Paraíba Region (hereinafter MPR), in order to identify conditions and trends in environmental sustainability and well-being. The MPR consists of twelve municipalities in an area that has undergone profound environmental changes since the $18^{\text {th }}$ century, which increased in the 19th century with the Coffee Cycle, and further intensified in the 1930s with the beginning of a growing industrialization and urbanization process.

\section{Environmental sustainability and health indicators from an ecosystem perspective}

As noted by Bellen 6 , there are difficulties in precisely defining the conditions for the sustainability of development without considering the existing difficulties for capturing sustainability's dynamics in a detailed or precise way. The current article assumes that sustainability should be based on the ethical principle of equity in relation to present and future generations, incorporating aspects of economic sustainability (employment, income, inequalities) and environmental sustainability (ecosystem services) together with human well-being 6,7.

Based on this principle, the indicators were grouped according to the conceptual framework proposed in the Millennium Ecosystem Assessment (MEA) 2, seeking to establish a relationship between ecosystem services and human well-being, based on a positive concept of health. This structure allows one to avoid treating "healthcare" and "health" as synonyms or encouraging the idea that medical care for disease is equal to health, reduced merely to the absence of diseas- es. From this perspective, the collected information integrated the economic and environmental dimensions that affect human well-being and health, incorporating aspects like employment and income distribution, living conditions, the state and sustainability of the environment, socio-environmental conflicts, and institutional conflict-resolution structures with social participation, as well as others that affect collective and individual well-being 8,9.

With regard to human well-being, the conceptual framework of the MEA 2 includes:

- Basic materials for a good life, involving the possibility of access to resources to sustain decent living.

- Health, involving the capacity to remain adequately fed and free of avoidable diseases and to live in a healthy environment

- Security, or the possibility to live in a secure environment and to reduce the vulnerability to ecological shocks and stresses.

- Good social relations, involving the opportunity to observe, study, and learn about the ecosystems and express aesthetic, cultural, and spiritual values and mutual respect and social cohesion.

- Freedom of choice and action: opportunity for individuals to achieve what is valuable to them. This component is a pre-condition for reaching others and is also affected by them.

When we assume that sustainability should be based on the ethical principle of equity, it follows that the greater the social exclusion and the less the human development (affecting the components of human well-being), the more the population groups in the municipalities and the MPR become vulnerable to environmental and health problems 10 . Greater vulnerability not only violates the ethical principle, but also restricts the opportunities for these same populations to contribute to environmental sustainability. Meanwhile, in a vicious circle, the degradation of ecosystem services tends to worsen the populations' living conditions and well-being, inducing further environmental exploitation and degradation in the struggle to guarantee daily survival. Precisely because populations become more vulnerable, they suffer in a more intense and expanded way the negative effects of environmental degradation caused by numerous economic activities that are increasingly connected to the global market, leaving a trail of environmental and health destruction where industrial processes and/or waste disposal are located 7,11.

Further in keeping with the MEA conceptual framework 2 (Figure 1), the indirect driving forces affect not only the direct driving forces that alter ecosystem services, but also directly and indirectly affect human well-being. In turn, when 
Conceptual framework for the interaction between human well-being, ecosystem services, and direct and indirect driving forces in ecosystem changes.

\section{SPATIAL SCALES}

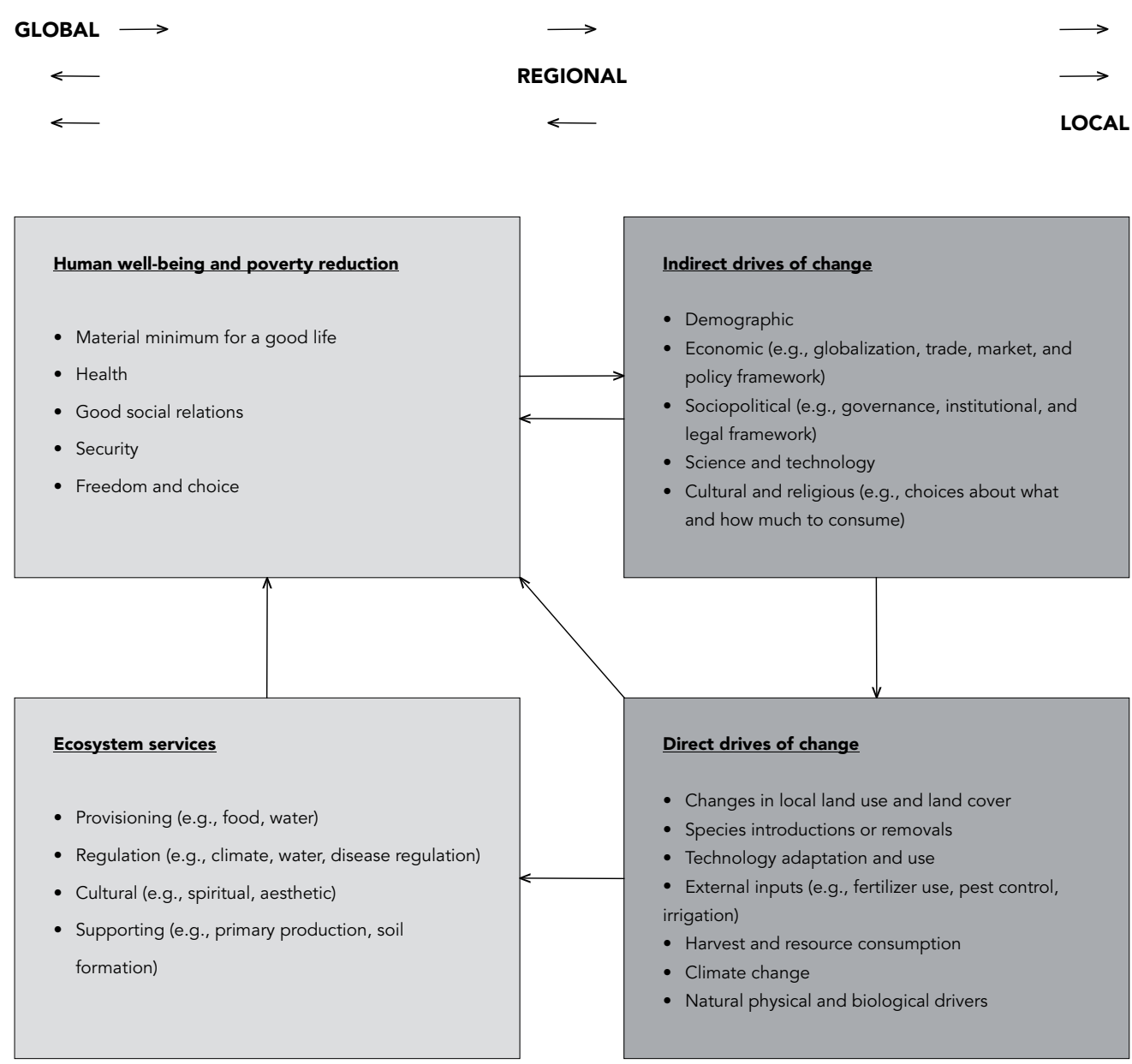

TEMPORAL SCALES

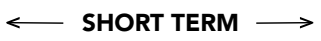

LONG TERM

Source: Millennium Ecosystem Assessment 2.

human well-being is affected, it ends up impacting the indirect driving forces, feeding back positively or negatively into the socio-environmental system. This process simultaneously involves different interconnected spatial (local, regional, and global) and temporal scales (short and long-term changes).
In this conceptual framework, the effects on health can be direct and indirect and may only occur after a long, complex network of events and situations combined on different spatial and temporal scales 12 (Table 1). This means that changes in ecosystems, coupled with given social and economic structures, can result in 
Typology of ecosystem health impacts.

\begin{tabular}{|c|c|c|c|c|}
\hline & Direct & Mediated & Modulated & Systems failure \\
\hline Causal mechanism & $\begin{array}{l}\text { Simple, necessary, } \\
\text { and sufficient exposures }\end{array}$ & $\begin{array}{c}\text { Necessary ecological } \\
\text { determinants }\end{array}$ & $\begin{array}{l}\text { Complex causation; } \\
\text { strong influence of } \\
\text { social factors }\end{array}$ & $\begin{array}{l}\text { Emergent properties, } \\
\text { thresholds, feedbacks }\end{array}$ \\
\hline Temporal scale & Days & Weeks/months & Years & Long term \\
\hline Spatial scale & Local & Local/regional & Regional & Global \\
\hline Number affected & Hundreds & Thousands & Millions & Millions/Billions \\
\hline Example & $\begin{array}{l}\text { Injury from extreme } \\
\text { climate event }\end{array}$ & $\begin{array}{c}\text { Communicable } \\
\text { disease transmission }\end{array}$ & $\begin{array}{l}\text { Regional famine, } \\
\text { major conflict }\end{array}$ & $\begin{array}{c}\text { Linked social- } \\
\text { ecological systems }\end{array}$ \\
\hline
\end{tabular}

Increasing length and complexity of causal web

Wider scale of distribution and impact

Increasing complexity and risk of "surprises"

More difficult to attribute and forecast

Source: Hales et al. 12.

direct effects from damage to ecosystem provision (of water for human consumption) or regulation (air purification or climate regulation), such as certain associated diseases (diarrheic diseases and acute respiratory infections). These effects, depending on the temporal scales (days, weeks, months, or decades) and spatial ones (local, regional, or global) can be direct, intermediate, or modulated, affecting hundreds to millions of people, involving all the way from environmental changes that alter vector and host distribution and behavior and droughts and floods that exacerbate infections originating from water for human consumption to abrupt changes with failures or breaks in the global environment system, like climate changes, requiring a long time for recovery or adaptation 12 .

This conceptual framework requires understanding the municipalities not as isolated territorial units confined to their administrative boundaries, but as members of a complex socio-environmental system in which the various responses to direct and indirect driving forces and the changes in human well-being and ecosystem services can produce positive or negative impacts.

Finally the databases and information sources that allowed gathering indicators within the proposed conceptual framework were the following: Rio de Janeiro Information and Data Center Foundation (CIDE: http://www.cide.rj.gov. br, accessed on 20/Dec/2003); Municipalities
Quality Index (IQM-Verde II) 13; Profile of Brazilian Municipalities - Public Administration 2001 (PBM-PA) 14; Profile of Brazilian Municipalities - Environment 2002 (PBM-Env) 15; Atlas of Social Exclusion in Brazil (ASE) 16; Atlas of Human Development in Brazil (AHD) 17; Mapping and Estimate of the Urbanized Area of Brazil (MEUA) 18; Map of Environmental Conflicts in the State of Rio de Janeiro (MEnvC) 19; Rio de Janeiro State Health Secretariat (SES-RJ: http://www.ses-rj.gov.br, accessed on 15/Mar/2006); National Health System Database (DATASUS: http:/ /www.datasus.gov.br, accessed on 20/Feb/2006).

\section{Indicators for the Middle Paraíba Region}

\section{Socioeconomic conditions}

According to data and information from the CIDE database, the MPR has the second largest population of all the regions in the State of Rio de Janeiro and consists of the following municipalities: Barra do Piraí, Barra Mansa, Itatiaia, Pinheiral, Piraí, Porto Real, Quatis, Resende, Rio Claro, Rio das Flores, Valença, and Volta Redonda.

The occupation and economic development process in the MPR began with the depletion of Brazil's so-called Gold Cycle (late 18th-early 19th centuries), with populations settling along the banks of the Paraíba do Sul River to farm and raise cattle. In the early $19^{\text {th }}$ century, these initial 
farming operations gave rise to the large coffee plantations as the main economic activity, resulting in the Coffee Cycle, with an economic boom and population growth. However, with the abolition of slavery (1888) and the depletion of farmland, coffee production steadily declined and finally came to a halt in the 20th century, when it was replaced by beef and dairy production. The 1930s witnessed the beginning of the industrialization process in some of the Middle Paraíba municipalities.

It was not until after World War II that the process of industrialization, population growth, and urbanization really took off. A milestone was the founding of the National Steel Company (CSN) in 1946, in Volta Redonda, serving as an attractor for a major portion of the Middle Paraíba municipalities and contributing directly and indirectly to the growth of the secondary and tertiary sectors.

As shown in Table 2, the population grew nearly fivefold from 1940 to 2000, and in areas where the municipality of Volta Redonda is now located, the population grew by 87 times. Meanwhile, the population became almost totally urban, from $37.2 \%$ in 1940 to $93 \%$ in 2000 , concentrated along the banks of the Paraíba do Sul River.

Table 3 shows how this urbanization process was accompanied by an intense increase in the population density in the urbanized areas, which in many municipalities represented less than $1 \%$ of the total area. In 2000 the overall population density in the MPR was 126.6 inhabitants $/ \mathrm{km}^{2}$, while in the urbanized areas it reached 8,480 inhabitants $/ \mathrm{km}^{2}$, with municipalities close to or even surpassing the population density of urbanized areas in large cities like Rio de Janeiro $(10,509$ inhabitants/km²) and São Paulo (10,134 inhabitants $/ \mathrm{km}^{2}$ ).

The Rio de Janeiro State land use and coverage map (Figure 2) shows that for the urban areas (pink) there is a major concentration in Volta Redonda-Barra Mansa (continuous) and another involving Resende-Itatiaia (continuous, but predominating in the former) and Porto Real (nearly continuous with the urban areas of Resende and Quatis). The forested areas (dark green) predominate in Itatiaia and Resende (and are continuous) along with natural high-altitude fields (lavender). The secondary vegetation areas (light green) are widely scattered and predominant in the Middle Paraíba municipalities, along with farm fields and pastures ( $\tan )$, resulting from intense deforestation since the 19th century.

The urbanized areas include the basis for the MPR economic structure, with the secondary sector of industry as the backbone, especially heavy industry. The corridor along the banks of the Paraíba do Sul River features factory clusters and projects with numerous industrial activities (metallurgy, chemicals/pharmaceuticals, nonmetallic minerals, lumber, hides and tanning, food products, and mechanics). This corridor's attractor is Volta Redonda (43\% of the MPR's GDP), and following the Paraíba do Sul River it crosses the municipalities of Barra Mansa and Porto Real, reaching the municipality of Resende. Thus, a major portion of the MPR infrastructure is focused on serving the industrial sector's needs. As an example, the industrial sector alone accounts for $78 \%$ or the region's electric power consumption.

Although the secondary sector has the largest share of the region's GDP and industrial establishments, in terms of employees the largest share is in commerce and services (43\%), with the tertiary sector accounting for $23 \%$. In the municipalities, formal jobs are located mainly in Volta Redonda (39\%), followed by Barra Mansa (18\%) and Resende (16\%). The MPR is characterized by loss in the number of formal jobs (from 1995 to 1999 , nearly a third were lost, totaling 56,700 ) and income concentration (of the total labor force, $19 \%$ were near the poverty line, earning until the minimum wage (U\$83/month in 2000), while $5 \%$ earned ten times the minimum wage or more).

\section{Environmental conditions}

Indicators of environmental conditions in the MPR were grouped from various sources: CIDE, IQM-Verde II 13, MEnvC 19, and MEUA 18, with the PBM-Env 15 adopted as the principal reference, given the somewhat limited availability of environmental data in Brazil, especially at the municipal level. The PBM-Env portrays the state of the environment in Brazilian municipalities from the municipal environmental manager's perspective, considering the Driving Forces and Pressures (DFP) acting on the air, water, and soil resources. According to the results obtained from this methodology, the managers indicated the occurrence of impacts (I) observed frequently in the state (S) of the local environment, even when the corresponding DFP were outside the municipality boundaries. Importantly, when a problem was identified by a large number of municipalities, it was not necessarily the worst or the one with the greatest impact, but rather reflected how it was perceived in its spatial scope.

While $41 \%$ of all Brazilian municipalities reported environmental changes that theyperceived as degrading the local living conditions, in the Middle Paraíba Region this figure reached $100 \%$ (Table 4). The environmental managers in these municipalities reported air pollution, water pollution, silting of waterways, soil contamination, and 
Population trend in the Middle Paraíba Region and Municipalities, by household situation, 1940-2000.

\begin{tabular}{|c|c|c|c|c|c|c|c|c|c|c|c|c|}
\hline \multirow[t]{2}{*}{ Municipalities } & \multicolumn{3}{|c|}{1940} & \multicolumn{3}{|c|}{1960} & \multicolumn{3}{|c|}{1980} & \multicolumn{3}{|c|}{2000} \\
\hline & Urban & Rural & Total & Urban & Rural & Total & Urban & Rural & Total & Urban & Rural & Total \\
\hline Middle Paraíba Region & 59,338 & 100,158 & 159,496 & 235,021 & 100,991 & 336,012 & 510,529 & 89,262 & 599,791 & 730,124 & 54,689 & 785,192 \\
\hline Barra do Piraí & 16,271 & 15,084 & 31,355 & 32,346 & 13,021 & 45,367 & 55,794 & 16,137 & 71,931 & 84,796 & 3,679 & 88,503 \\
\hline Barra Mansa & 9,916 & 9,369 & 19,285 & 49,201 & 9,301 & 58,502 & 130,422 & 16,328 & 146,750 & 164,963 & 5,630 & 170,753 \\
\hline Itatiaia & 838 & 3,112 & 3,950 & 2,969 & 2,447 & 5,416 & 8,630 & 3,664 & 12,294 & 11,731 & 12,998 & 24,739 \\
\hline Pinheiral & 927 & 1,052 & 1,979 & 3,642 & 1,425 & 5,067 & 9,003 & 570 & 9,573 & 17,674 & 1,807 & 19,481 \\
\hline Piraí & 2,102 & 12,052 & 14,154 & 4,752 & 13,231 & 17,983 & 12,792 & 6,421 & 19,213 & 18,035 & 4,044 & 22,118 \\
\hline Porto Real & 326 & 688 & 1,014 & 40 & 2,697 & 2,737 & 1,732 & 4,440 & 6,172 & 11,385 & 707 & 12,095 \\
\hline Quatis & 1,527 & 2,752 & 4,279 & 2,335 & 2,977 & 5,312 & 5,523 & 2,468 & 7,991 & 9,388 & 1,311 & 10,730 \\
\hline Resende & 9,270 & 13,188 & 22,458 & 26,658 & 13,986 & 40,644 & 57,660 & 11,209 & 68,869 & 95,893 & 8,589 & 104,549 \\
\hline Rio Claro & 2,244 & 12,649 & 14,893 & 3,629 & 11,605 & 15,234 & 6,443 & 6,471 & 12,914 & 11,620 & 4,612 & 16,228 \\
\hline Rio das Flores & 1,238 & 6,482 & 7,720 & 1,794 & 6,444 & 8,238 & 2,620 & 4,246 & 6,866 & 5,355 & 2,260 & 7,625 \\
\hline Valença & 13,662 & 21,965 & 35,627 & 23,682 & 19,090 & 42,772 & 39,784 & 13,793 & 53,577 & 57,304 & 8,986 & 66,308 \\
\hline Volta Redonda & 1,017 & 1,765 & 2,782 & 83,973 & 4,767 & 88,740 & 180,126 & 3,515 & 183,641 & 241,980 & 66 & 242,063 \\
\hline
\end{tabular}

Source: Rio de Janeiro Information and Data Center Foundation (CIDE: http://www.cide.rj.gov.br, accessed on 20/Dec/2003).

Table 3

Total and urban population in 2000, total and urban area, percentage of urbanized area, total population density (inhabitants/km²) and in urbanized areas

\begin{tabular}{|c|c|c|c|c|c|c|c|c|}
\hline Municipalities & $\begin{array}{c}\text { Total } \\
\text { population }\end{array}$ & $\begin{array}{c}\text { Urban } \\
\text { population }\end{array}$ & $\begin{array}{c}\text { Urban } \\
\text { population (\%) }\end{array}$ & $\begin{array}{c}\text { Total } \\
\text { area }\left(\mathrm{km}^{2}\right)\end{array}$ & $\begin{array}{l}\text { Urbanized } \\
\text { areas }\left(\mathrm{km}^{2}\right)\end{array}$ & $\begin{array}{c}\text { Urban } \\
\text { area (\%) }\end{array}$ & $\begin{array}{c}\text { Population } \\
\text { density } \\
\text { (inhabitants/ } \\
\mathrm{km}^{2} \text { ) in } \\
\text { total area }\end{array}$ & $\begin{array}{l}\text { Population } \\
\text { density } \\
\text { (inhabitants/ } \\
\text { km²) in urba- } \text { nized areas }\end{array}$ \\
\hline Middle Paraíba Region & 785,192 & 730,482 & 93.0 & $6,205.1$ & 86.1 & 1.4 & 126.6 & 8,480 \\
\hline Barra do Piraí & 88,503 & 84,816 & 95.8 & 579.8 & 2.2 & 0.4 & 152.0 & 38,238 \\
\hline Barra Mansa & 170,753 & 165,134 & 96.7 & 548.9 & 16.5 & 3.0 & 311.6 & 10,026 \\
\hline Itatiaia & 24,739 & 11,728 & 47.4 & 225.5 & 2.6 & 1.1 & 102.3 & 4,537 \\
\hline Pinheiral & 19,481 & 17,672 & 90.7 & 77.0 & 3.4 & 4.4 & 250.4 & 5,165 \\
\hline Piraí & 22,118 & 18,070 & 81.7 & 506.7 & 3.5 & 0.7 & 43.8 & 5,197 \\
\hline Porto Real & 12,095 & 11,388 & 94.2 & 50.7 & 2.5 & 5.0 & 237.6 & 4,490 \\
\hline Quatis & 10,730 & 9,412 & 87.7 & 286.9 & 2.3 & 0.8 & 37.4 & 4,174 \\
\hline Resende & 104,549 & 95,963 & 91.8 & $1,116.2$ & 13.1 & 1.2 & 95.0 & 7,312 \\
\hline Rio Claro & 16,228 & 11,616 & 71.6 & 843.5 & 2.6 & 0.3 & 19.2 & 4,522 \\
\hline Rio das Flores & 7,625 & 5,364 & 70.3 & 479.0 & 1.7 & 0.3 & 15.9 & 3,206 \\
\hline Valença & 66,308 & 57,323 & 86.4 & $1,308.1$ & 8.6 & 0.7 & 50.8 & 6,633 \\
\hline Volta Redonda & 242,063 & 241,996 & 99.9 & 182.8 & 27.2 & 14.9 & $1,330.0$ & 8,907 \\
\hline
\end{tabular}

Sources: Rio de Janeiro Information and Data Center Foundation (CIDE: http://www.cide.rj.gov.br, accessed on 20/Dec/2003); Miranda et al. 18.

environmental changes that were harmful to the landscape or protected areas as the most damaging environmental problems in the degradation of the region's living conditions. In this same context, the DFP were also perceived as closely linked to these impacts: in the case of air pollution, veg- etation fire and industrial and vehicle emissions; for water pollution, livestock production, industrial effluents, household sewage, solid waste, and irregular occupation of waterways; for silting, the landfill along riverbanks, degradation of ciliary areas, erosion, and landslides and deforestation; 


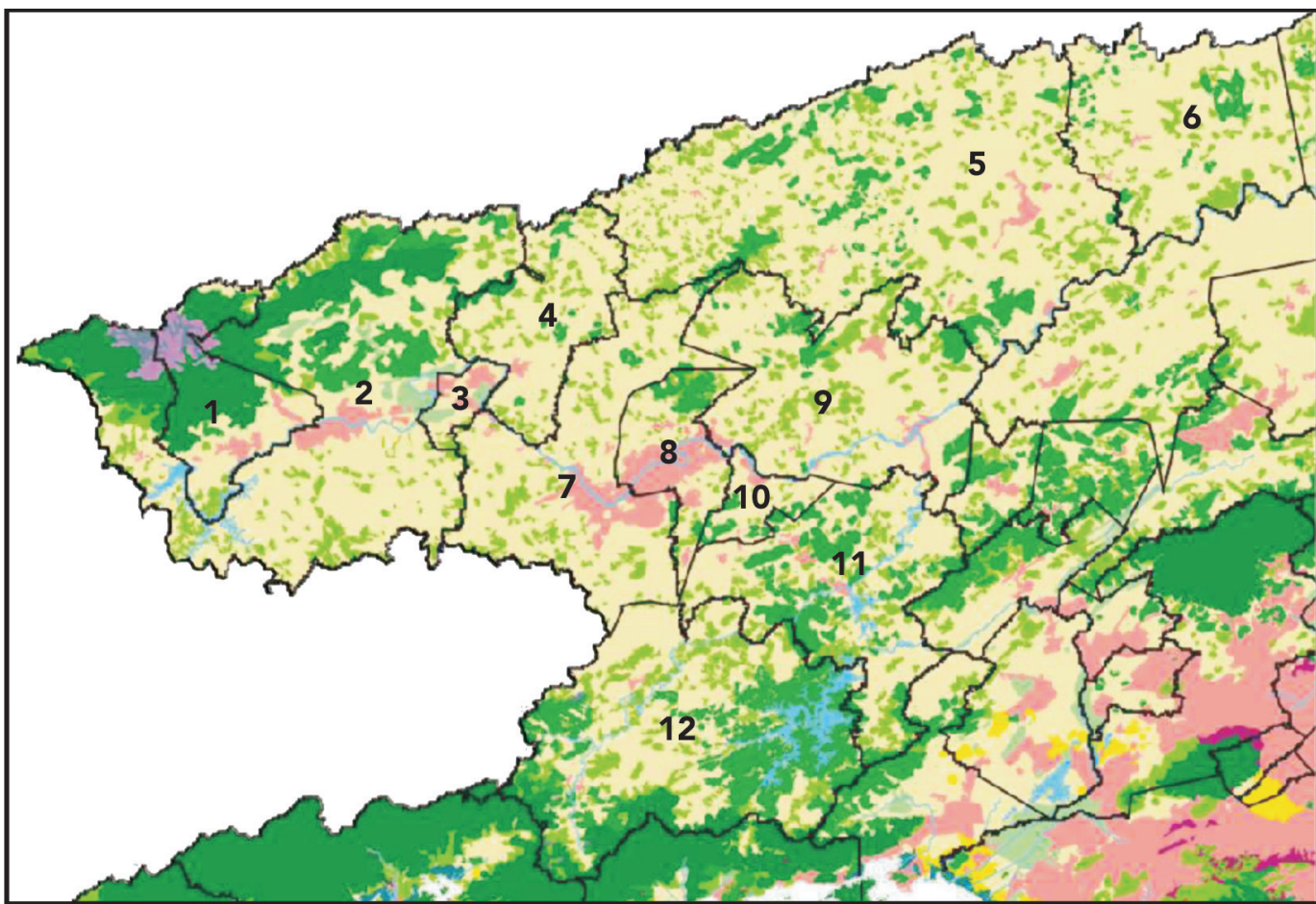

Field/Pasture
Culture
Crops

Wetland
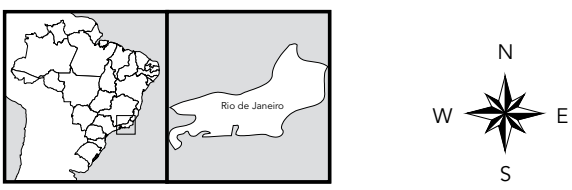

Mountain savannah

Waterways, lakes/lagoons, reservoirs

\begin{tabular}{|ll|}
\hline \multicolumn{2}{|c|}{ Municipalities } \\
1 - Itatiaia & 7 - Barra Mansa \\
2 - Resende & - Volta Redonda \\
3 - Porto Real & 9 - Barra do Piraí \\
4 - Quatis & 10 - Pinheiral \\
5 - Valença & 11 - Piraí \\
6 - Rio das Flores & 12 - Rio Claro \\
\hline
\end{tabular}

Source: Rio de Janeiro Information and Data Center Foundation (CIDE: http://www.cide.rj.gov.br, accessed on 20/Dec/2003).

for environmental changes affecting the soil and landscape, once again deforestation along with erosion and irregular (and/or disordered) land occupation and new real estate developments. Finally, unauthorized timbering and fishing appear as the DFP producing the heaviest degradation of legally protected areas.

From the ecosystem perspective, in the final analysis the indirect driving forces generating direct driving forces (equivalent to pressures) that 
Environmental impacts perceived as degrading the living conditions in the Middle Paraíba Region, Rio de Janeiro State, Brazil.

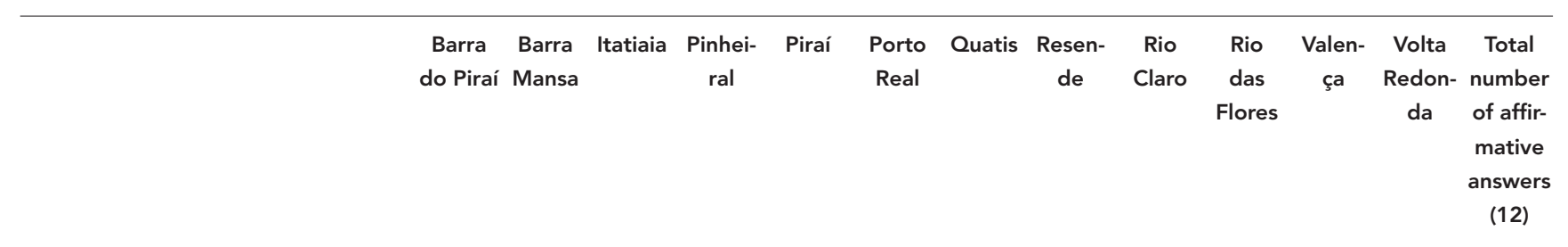

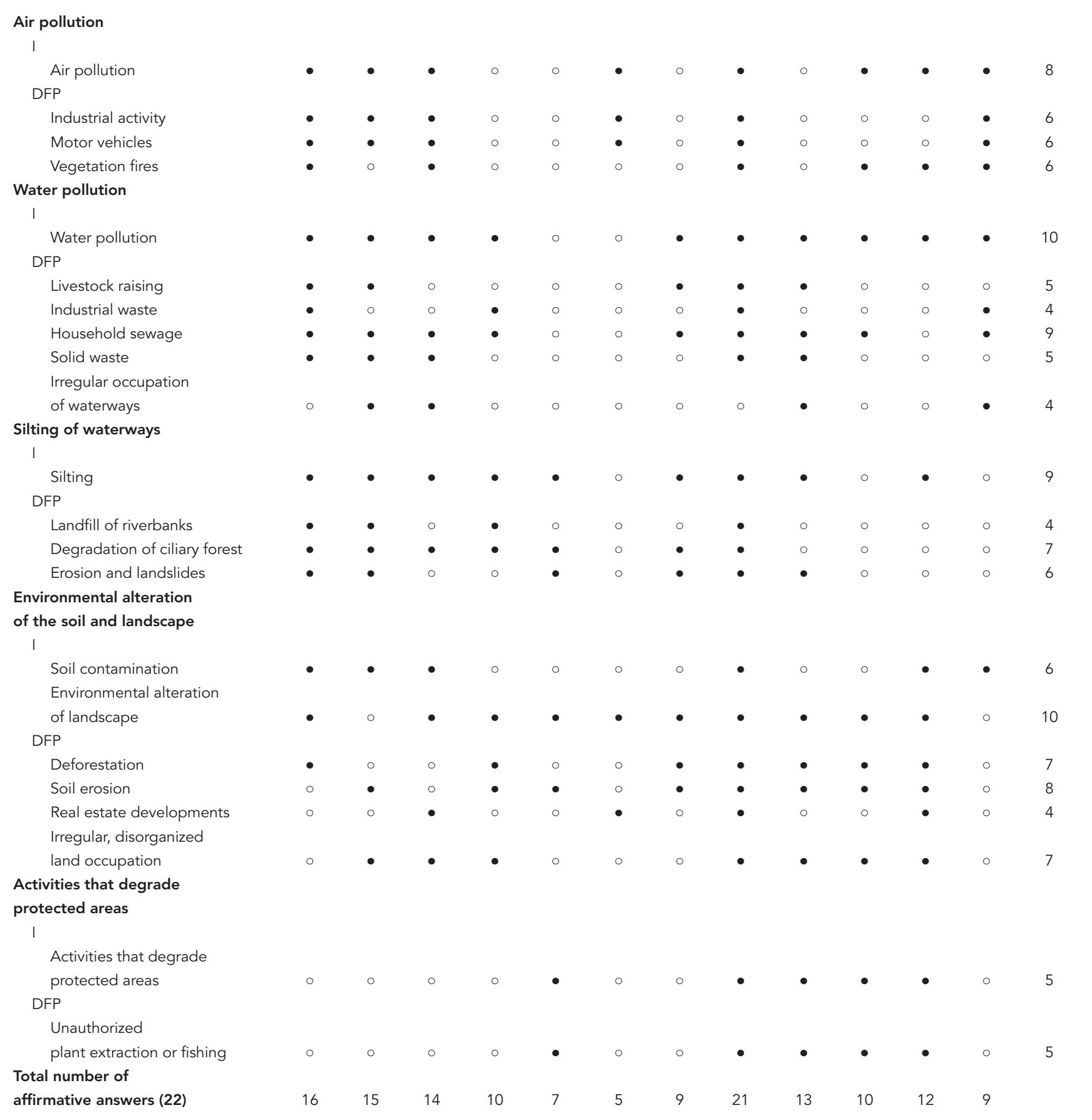

- Yes;

○ No.

I: occurrence of impacts; DFP: driving forces and pressures. 
impact the environment respond to the presence of an attractor ${ }^{20}$. In the MPR as a whole, the principal attractor is industrial activity; however in municipalities like Itatiaia and Valença, many of the observed environmental impacts result from the attractor effect of tourism. Beginning in the 1930, the region's industrialization process replaced coffee-growing, another attractor that had been prevalent in the 19th century but which had declined in the early $20^{\text {th }}$ century; however, the industrialization process, population growth, and urbanization really took off with the creation of the CSN in Volta Redonda.

Coffee growing left an environmental liability with the combined results of extensive and intensive monoculture: primary deforestation, soil depletion, drying up of springs, silting of waterways, and erosion among other environmental impacts. Predatory farming in the Paraíba Valley, which destroyed large stretches of forests, including slashing and vegetation fire, especially on hillsides, resulted in the depletion of soil for other crops, climate imbalances, and the extinction of primary forest, to the point that two-thirds of the region's municipalities were left with less than $1 \%$ of forest cover 13 . The economic decadence of the MPR set in, and beef and dairy production became its main economic activities, further degrading the environment; with less demand for labor, another result was a rural exodus to urban areas in search of better living conditions 21 .

Tourism also acts as an attractor in the municipalities that have conserved forest areas and tourist attractions, like Penedo, with the Itatiaia National Park, located in the municipality of the same name, and the Agulhas Negras Park and the Visconde de Mauá area in the municipality of Resende. According to the IQM-Verde II database 13, except for this block of forests located in the municipalities of Itatiaia and Resende, the forest cover in the rest of the region consists of numerous small fragments of primary and secondary vegetation (shown in dark and light green in Figure 2), resulting in the impoverishment of animal and plant species, altered genetic diversity and species composition in various locations, and greater plant and animal vulnerability in each fragment, which can dwindle to extinction, among other reasons due to invading species 22 .

Farming activities were also perceived as degrading driving forces for the local environment, especially livestock-raising, identified as a source of water pollution. With the exception of Itatiaia, more than $50 \%$ of the territory in the municipalities is devoted to fields and pastures 13 , involving the traditional practice of burning fields, pastures, and native vegetation in order to prepare the land for farming and renewing the pastures, with negative impacts on the soil, vegetation, biodiversity, and air quality 15 .

Figure 3 attempts to integrate the direct driving forces (Figure 1) with an environmental impact leading to losses in human well-being and health in the MPR, based on the perceptions of environmental managers as shown in Table 4 . The losses result from indirect driving forces associated with the land occupation and appropriation of natural resources in the MPR, which aggravate the process of environmental degradation when not properly planned and organized.

According to the data in Table 4, among the activities contributing to water pollution, the most widely perceived DFP was dumping household sewage into waterways as a result of deficient basic sanitation services and reflecting the lack of human development that leads to irregular, disorganized occupation of the territory. In the MPR, only four municipalities (Barra Mansa, Pinheiral, Resende, and Volta Redonda) have more than $75 \%$ of households connected to the public sewage system, and in Rio Claro the coverage is less than $50 \%$. Throughout the region, dumping raw sewage directly into waterways is still commonplace, contributing to water pollution throughout the region and particularly in the Paraíba do Sul River (Rio de Janeiro Information and Data Center Foundation. http://www.cide. rj.gov.br, accessed on 20/Dec/2003).

Inadequate solid waste management and garbage disposal is also perceived as contributing to water pollution. According to the CIDE database, 696 tons of solid waste are produced per day in the MPR, $39 \%$ of which in the municipality of Volta Redonda alone, followed by Barra Mansa (17\%), and Resende (15\%). In relation to the destination of garbage, of the 56 units identified, $64 \%$ are open-air dumps, the only type of destination in half of the municipalities (Barra do Piraí, Pinheiral, Piraí, Rio Claro, Rio das Flores, and Valença). Some 185 tons a day, or one-fourth of the solid waste collected, are unloaded in garbage dumps with no environmental or public health protective measures, rather than in proper sanitary landfills. Further aggravating this situation is the fact that a large percentage of households in the majority of the municipalities have no access to the public sewage system, and the use of crude cesspools is still common.

In relation to industrial waste, eight of the ten environmental conflicts identified in the MPR from 1992 to 2002 were related to environmental contamination caused by legal or illegal disposal, resulting in soil or water contamination in the municipalities of Itatiaia $(n=2)$, Resende $(n=3)$, and Volta Redonda $(n=3)$. 
Direct driving forces with an environmental impact leading to losses in human well-being and health in Middle Paraíba Region, Rio de Janeiro State, Brazil.

ENVIRONMENTAL DEGRADATION OF THE SOIL AND LANDSCAPE

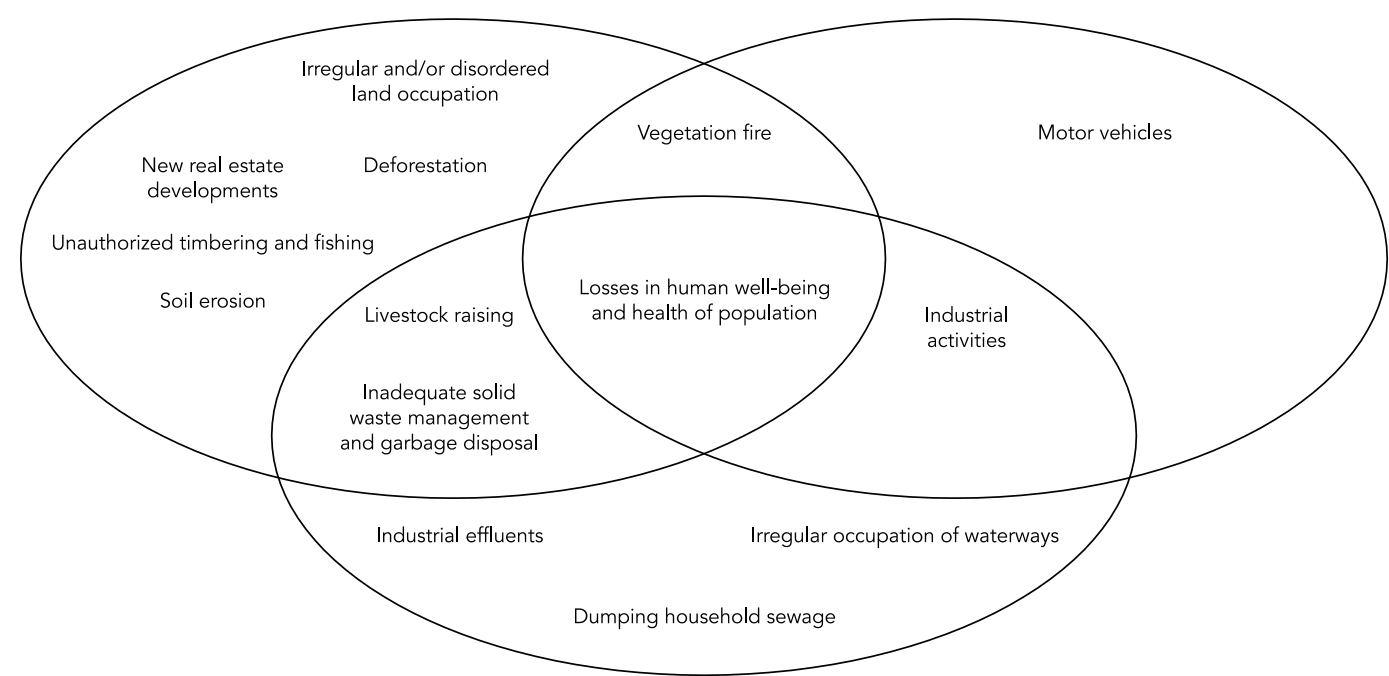

WATER POLLUTION

Source: Brazilian Institute of Geography and Statistics 15.

Finally, in relation to the environmental degradation of legally protected areas, vegetation fires were perceived as the principal environmental impact pressure, followed by deforestation and illegal plant extraction (illegal harvesting of protected hardwoods, hearts-of-palm, and rare plants). These three causes are still basically connected to the original forms of land occupation, especially beginning in the 19th century, when burning, deforestation, and plant extraction formed the main thrust of economy activities in the area.

\section{Human well-being}

Considering health as a component of human well-being, an attempt was made to group the data from multiple sources: CIDE, ASE 16, AHD 17, SES-RJ, and DATASUS.

For the ASE indicators, the same values were adopted as those defined by the authors 16 . The same values were adopted for the Municipal $\mathrm{Hu}$ man Development Index (MHDI), and the lowest bracket (0.000 to 0.499$)$ was divided in two, so that 0.000 to 2.499 was the group with the worst situation as measured by this index. In the health component, in addition to the longevity indicator, which expresses the dimension of living a long and healthy life, two other indicators were used that are associated with under-five mortality: proportional mortality from diarrheic diseases in under-fives (ICD-10 codes A00 to A09) and proportional mortality from acute respiratory infections (ARI) in under-fives (ICD-10 codes J00 to J22). For the municipalities, we used the data available on the website for the SES-RJ from 1999 to 2005. Definition of the values was based on the data available from the DATASUS from 1999 to 2002, in which the worst indicator for under-five proportional mortality from diarrheic disease was 7.48 in the Northeast Region of Brazil, and the worst indicator for acute respiratory infections was 6.45 , in the North. We took 7.0 as an arbitrary cutoff and divided by four, resulting in the classification shown in the key to Table 5.

As a criterion, the lower the values referring to social exclusion and human development, the worse the components of human well-being and the greater the population's vulnerability to environmental and health problems. For the propor- 
tional mortality indices, the higher the value, the greater the vulnerability. To facilitate the indicators' communicative effect, at the extremes we have dark grey, indicating the situations with the greatest vulnerability and which merit the most attention and demand immediate reversal. At the other extreme, light grey indicates the more favorable situations.

In the component basic materials for a good life (Table 5), only the MHDI-Income shows a situation of medium-low vulnerability. This is due to the very limitation of the HDI, since per capita GDP becomes synonymous with "economic development" and fails to consider social inequalities and processes of social exclusion. Inclusion of the poverty index increases the vulnerability (medium-high in four MPR municipalities). According to the inequality index, eight municipalities show medium-high vulnerability, and at the extremes Resende shows a favorable situation and Rio das Flores shows vulnerability. The employment index shows a situation requiring considerable attention, since three-fourths of the municipalities display high vulnerability and the others medium-high. The downward trend in formal employment and the increased casualization of labor (coupled with the process of inequalities and poverty that often follow in their wake) restrict the access to basic materials for a good life and human well-being, constituting greater vulnerability in terms of the social conditions needed for present and future environmental sustainability and health in the MPR.

The security component drew on youth and violence indices, both focused on evaluating the exposure of the young population to situations of violence, in addition to the social exclusion index. Although violence cannot be considered a result of the degradation of ecosystem services, it does express a consequence of the combined effects of economic stagnation and unemployment, the spread of consumerist values, and increased socioeconomic inequality and precarious living conditions in degraded environments 16,23 . Thus, although the violence and youth indices are low in nearly all the municipalities, some of their causes are present, like the loss of jobs and expansion of socioeconomic inequalities in nearly all the municipalities, leaving more than one-third of the young population vulnerable and prone to become a future threat to well-being and environmental sustainability and health of the MPR, considering that they will be adults and then elderly 25 and 50 years in the future. The fact that social exclusion demands attention in 10 of the $12 \mathrm{mu}$ nicipalities and that it tends to affect the other previous two indices underlines that environ- mental vulnerability cannot be dissociated from social vulnerability, since the latter intensifies the former, while jeopardizing the social fabric, so vital to sustainability.

The health component used the longevity indicator together with two other indicators related to under-five mortality. The latter indicate unsatisfactory socioeconomic conditions and insufficient basic healthcare in terms of coverage and quality for children; while acute diarrheic diseases are related to precarious sanitation, acute respiratory infections are associated with climatic factors 24

According to Table 5, Quatis is the municipality with the best longevity index, with all the others were classified as medium-low vulnerability. Proportional mortality due to acute diarrheic diseases only appears as an indicator of high vulnerability in Rio Claro, which in 2000 was the municipality with the lowest proportion $(45.4 \%)$ of households connected to the public sewage system and the highest proportion (10.9\%) of households with crude cesspits. Proportional mortality due to acute respiratory infections appears as an indicator of high or medium-high vulnerability in three-fourths of the municipalities and may reflect the combination of sharp socioeconomic inequality with climatic and environmental changes associated with pollution, especially due to slashing and burning, which is among the direct driving forces of environmental impacts affecting ecosystem regulation services, including air purification and climatic regulation in the municipalities and the region as a whole.

The good social relations component (Table 5) used the literacy, schooling, and education indices, all including the dimension of knowledge and the population's symbolic and cultural background. It also included the MHDI itself, considering that even with limitations, the better the index, the lower the vulnerability to deterioration of the social fabric. The indices were felt to be at the basis of the possibility for expanding the potential to observe, study, and learn about the ecosystems, while increasing the opportunity to express aesthetic, cultural, and spiritual values beyond those centered on consumption. They also help strengthen mutual respect and social cohesion, vital for reducing socio-environmental vulnerability and increasing the population's possibility of increasing its security as a component of well-being.

In relation to MHDI and MHDI-Education, the situation is good in all the municipalities. As for the literacy rate, the only municipality that requires attention is Rio Claro, and for schooling, most of the municipalities showed medium-low vulnerability, with only two (Rio Claro and Rio 
Table 5

Components of human well-being by municipality.

\begin{tabular}{|c|c|c|c|c|c|c|c|}
\hline \multirow[t]{2}{*}{ Municipalities } & \multicolumn{4}{|c|}{ Basic material for a good life } & \multicolumn{3}{|c|}{ Security } \\
\hline & $\begin{array}{l}\text { Poverty } \\
\text { rate }\end{array}$ & $\begin{array}{c}\text { Employment } \\
\text { rate }\end{array}$ & $\begin{array}{c}\text { Inequality } \\
\text { index }\end{array}$ & $\begin{array}{c}\text { HDI- } \\
\text { Income }\end{array}$ & $\begin{array}{l}\text { Youth } \\
\text { index }\end{array}$ & $\begin{array}{l}\text { Violence } \\
\text { index }\end{array}$ & $\begin{array}{c}\text { Social } \\
\text { exclusion } \\
\text { index }\end{array}$ \\
\hline Barra do Piraí & 0.668 & 0.166 & 0.128 & 0.710 & 0.797 & 0.957 & 0.565 \\
\hline Barra Mansa & 0.682 & 0.167 & 0.126 & 0.720 & 0.765 & 0.847 & 0.543 \\
\hline Itatiaia & 0.695 & 0.248 & 0.196 & 0.720 & 0.707 & 0.984 & 0.584 \\
\hline Pinheiral & 0.642 & 0.074 & 0.106 & 0.690 & 0.728 & 0.960 & 0.524 \\
\hline Piraí & 0.583 & 0.232 & 0.132 & 0.700 & 0.752 & 0.908 & 0.534 \\
\hline Porto Real & 0.611 & 0.203 & 0.071 & 0.670 & 0.676 & 0.917 & 0.508 \\
\hline Quatis & 0.638 & 0.131 & 0.109 & 0.690 & 0.718 & 0.964 & 0.523 \\
\hline Resende & 0.734 & 0.251 & 0.275 & 0.760 & 0.739 & 0.920 & 0.608 \\
\hline Rio Claro & 0.562 & 0.105 & 0.078 & 0.660 & 0.728 & 0.898 & 0.48 \\
\hline Rio das Flores & 0.446 & 0.15 & 0.067 & 0.650 & 0.728 & 0.877 & 0.469 \\
\hline Valença & 0.59 & 0.203 & 0.128 & 0.710 & 0.780 & 0.969 & 0.553 \\
\hline Volta Redonda & 0.745 & 0.252 & 0.214 & 0.750 & 0.787 & 0.810 & 0.596 \\
\hline \multirow[t]{2}{*}{ Municipalies } & & \multicolumn{2}{|c|}{ Health } & \multicolumn{4}{|c|}{ Good social relations } \\
\hline & $\begin{array}{l}\text { Longevity } \\
\text { index }\end{array}$ & $\begin{array}{c}\text { Proportional } \\
\text { mortality } \\
\text { from diarrheic } \\
\text { diseases in < } 5\end{array}$ & $\begin{array}{c}\text { Proportional } \\
\text { mortality from } \\
\text { ARI in }<5\end{array}$ & $\begin{array}{l}\text { Literacy } \\
\text { rate }\end{array}$ & $\begin{array}{l}\text { Schooling } \\
\text { rate }\end{array}$ & $\begin{array}{c}\text { MHDI- } \\
\text { Education }\end{array}$ & MHDI \\
\hline Barra do Piraí & 0.730 & 1.0 & 4.8 & 0.900 & 0.631 & 0.910 & 0.910 \\
\hline Barra Mansa & 0.790 & 1.1 & 6.1 & 0.905 & 0.608 & 0.910 & 0.910 \\
\hline Itatiaia & 0.780 & 3.2 & 1.6 & 0.883 & 0.635 & 0.900 & 0.900 \\
\hline Pinheiral & 0.790 & 2.3 & 4.5 & 0.879 & 0.589 & 0.910 & 0.910 \\
\hline Piraí & 0.750 & 2.6 & 2.6 & 0.858 & 0.536 & 0.880 & 0.880 \\
\hline Porto Real & 0.690 & 2.3 & 7 & 0.850 & 0.501 & 0.870 & 0.870 \\
\hline Quatis & 0.820 & 3.3 & 6.7 & 0.855 & 0.52 & 0.870 & 0.870 \\
\hline Resende & 0.750 & 1.8 & 2.9 & 0.892 & 0.705 & 0.920 & 0.920 \\
\hline Rio Claro & 0.750 & 7.7 & 7.7 & 0.795 & 0.439 & 0.800 & 0.800 \\
\hline Rio das Flores & 0.730 & 0 & 10 & 0.837 & 0.473 & 0.850 & 0.850 \\
\hline Valença & 0.730 & 2.1 & 5.8 & 0.876 & 0.608 & 0.900 & 0.900 \\
\hline Volta Redonda & 0.760 & 1.8 & 3.3 & 0.917 & 0.727 & 0.930 & 0.930 \\
\hline
\end{tabular}

Table of values adopted:

\begin{tabular}{|c|c|c|c|c|c|c|c|c|c|c|}
\hline & Exclusion & Poverty & Employment & Inequality & Literacy & Schooling & Youth & Violence & MHDI & $\begin{array}{c}\text { Proportional } \\
\text { mortality }\end{array}$ \\
\hline High & $0.000-0.312$ & $0.000-0.187$ & $0.000-0.218$ & $0.000-0.068$ & $0.000-0.312$ & $0.000-0.244$ & $0.000-0.287$ & $0.000-0.466$ & $0.000-0.2499$ & $>5.4$ \\
\hline Medium-high & $0.313-0.381$ & $0.188-0.609$ & $0.219-0.342$ & $0.069-0.153$ & $0.313-0.653$ & $0.245-0.422$ & $0.288-0.514$ & $0.467-0.737$ & $0.250-0.499$ & $3.6-5.3$ \\
\hline Medium-low & $0.382-0.588$ & $0.610-0.748$ & $0.343-0596$ & $0.154-0.228$ & $0.654-0.806$ & $0.423-0.505$ & $0.515-0.700$ & $0.738-0.865$ & 0.500-0.799 & $1.8-3.5$ \\
\hline Low & $0.589-1.000$ & $0.749-1.000$ & $0.597-1.000$ & $0.229-1.000$ & $0.807-1.000$ & $0.506-1.000$ & $0.701-1.000$ & $0.866-1.000$ & $0.800-1.000$ & $<1.7$ \\
\hline
\end{tabular}

HDI: Human development index; ARI: acute respiratory infection; MDHI: Municipal human development index.

Source: Campos et al. 16; João Pinheiro Foundation 17; Rio de Janeiro State Health Secretariat (SES-RJ: http://www.ses-rj.gov.br, accessed on 15/Mar/2006) 
das Flores) showing medium-high vulnerability, the same situation as for social exclusion.

\section{Institutional structure for sustainability}

One of the basic requirements for sustainability is to structure the capacity for social response to the direct and indirect driving forces that impact the environment and jeopardize the ecosystem services and human health and well-being. The requirements of this response are institutionalization and strengthening of state action, as well as greater participation by society. The data for this item come from the PBM-PA 14 and PBM-Env 15 and include the existence of municipal secretariats and councils and Agenda 21.

During the 1980s, with the 1988 National Constitution as the main reference, Brazil established legal frameworks for the decentralization of municipal government activities and greater participation by society in the so-called municipal (community-based) councils, which grew during the 1990s. In terms of indicators of institutional structure, the focus was on the municipal councils for health, viewed as a basic component of human well-being and affected by it, and the environment.

As for the health sector, all of the municipalities have municipal health secretariats (or departments). However, only seven municipalities (58\%) had environmental secretariats in 2001 (Table 6), and of these only three (43\%) dealt exclusively with the environment. These data are different from the overall situation for Brazil, since $68 \%$ of the country's municipalities as a whole had some kind of structure related to the environmental area, but of these only $9 \%$ dealt exclusively with the environment itself 14 .

By allowing the expansion of different forms of participation by society and promoting new relations between the state and society for dealing with issues like health and the environment, the municipal councils become vital for democracy and sustainability. They allow debate on public issues, proposing solutions, participation in decision-making, consultancy, and follow-up on decision-making processes and government action at the local level 15 .

As for the Municipal Health Councils, as shown in Table 6, in 2001 all the municipalities had councils and held at least monthly meetings with equal participation between government and civil society, except for Volta Redonda. Eight municipalities (67\%) had Municipal Environmental Councils, but only 3 (37.5\%) had equal representation between government and civil society and held meetings, in two cases monthly and in the other cases on an irregular basis. For
Brazil as a whole, in the year 2001, 97\% of municipalities had Municipal Health Councils, and of these $86 \%$ held regular meetings throughout the year $(92 \%$ had equal participation between government and civil society). In that same year $29 \%$ of Brazil's municipalities had Municipal Environmental Councils, of which $69 \%$ held regular meetings throughout the year and $64 \%$ had equal participation 14 .

To complement the Municipal Councils, the existence of a Local Agenda 21 is an important indicator, since it is expected to result from a participatory, multi-sector process for building a strategic action program for local sustainability (establishing Local Agenda 21 Forums is vital for this purpose) 15. As shown in Table 6, in 2002 seven municipalities (58\%) in the Middle Paraíba Region had begun the Local Agenda 21 process, and $71 \%$ of this total had Forums. In Brazil as a whole, some $30 \%$ had launched the Agenda 21 process, of which nearly half had already set up Forums. Implementation of Agenda 21 without a Forum jeopardizes the process, since its principal mission is to represent the interests of the community as a whole during the elaboration and implementation of the Local Sustainable Development Plan 14

The institutional structure for sustainability in the MPR is still insufficient, particularly in the environmental sector, both in terms of the existence of Municipal Environmental Secretariats and Environmental Councils with regular meetings and equal participation by government and society. Even for Local Agenda 21, where the situation in the MPR is better than for the country as a whole, only a third of the municipalities had launched the process and implemented a Forum.

In addition, considering that the municipalities belong to a complex socio-environmental system in which the individual institutional responses (secretariats, councils, and Local Agenda 21) can affect the others positively or negatively, it is also important to consider the existence of spheres and actions belonging to the different municipalities. The Middle Paraíba Region features some initiatives that involve all the various municipalities: in particular, the environmental sector has the Committee for the Integration of the Paraíba do Sul River Basin (CEIVAP), created by law in 1996, and the health sector has the Middle Paraíba Inter-Municipal Health Consortium, established in 1998 with the purpose of developing health services organizational activities, as well as the Regionalization Master Plan of the Rio de Janeiro State Health Secretariat, based on the so-called 2001 Healthcare Operational Standard, allowing further progress in healthcare regionalization by organizing and linking inter-municipal 
Characteristics of municipal health and environmental councils, environmental secretariats, and local Agenda 21 in the Middle Paraíba Region, Rio de Janeiro State, Brazil, 2001-2002

\begin{tabular}{|c|c|c|c|c|c|c|c|c|c|c|c|c|}
\hline & \multicolumn{2}{|c|}{$\begin{array}{l}\text { Municipal environmental } \\
\text { secretariats }\end{array}$} & \multicolumn{4}{|c|}{ Municipal health councils } & \multicolumn{4}{|c|}{$\begin{array}{l}\text { Municipal environmental } \\
\text { councils }\end{array}$} & \multicolumn{2}{|c|}{ Local Agenda 21} \\
\hline & $\begin{array}{c}\text { Exis- } \\
\text { tence } \\
\text { of a } \\
\text { muni- } \\
\text { cipal } \\
\text { environ- } \\
\text { mental } \\
\text { secre- } \\
\text { tariat }\end{array}$ & $\begin{array}{c}\text { Secre- } \\
\text { tariat } \\
\text { devo- } \\
\text { ted } \\
\text { solely } \\
\text { and ex- } \\
\text { clusively } \\
\text { to the } \\
\text { enviro- } \\
\text { nment }\end{array}$ & $\begin{array}{l}\text { Exis- } \\
\text { tence } \\
\text { of muni- } \\
\text { cipal } \\
\text { health } \\
\text { councils }\end{array}$ & $\begin{array}{c}\text { Held } \\
\text { meetings } \\
\text { in } \\
2001\end{array}$ & $\begin{array}{l}\text { Periodi- } \\
\text { city } \\
\text { of } \\
\text { meetings }\end{array}$ & $\begin{array}{l}\text { Equal } \\
\text { partici- } \\
\text { pation } \\
\text { by } \\
\text { govern- } \\
\text { ment/civil } \\
\text { society }\end{array}$ & $\begin{array}{c}\text { Exis- } \\
\text { tence } \\
\text { of a } \\
\text { muni- } \\
\text { cipal } \\
\text { environ- } \\
\text { mental } \\
\text { councils }\end{array}$ & $\begin{array}{l}\text { Held } \\
\text { meetings } \\
\text { in } \\
2001\end{array}$ & $\begin{array}{l}\text { Periodi- } \\
\text { city } \\
\text { of } \\
\text { meetings }\end{array}$ & $\begin{array}{l}\text { Equal } \\
\text { partici- } \\
\text { pation } \\
\text { by } \\
\text { govern- } \\
\text { ment/civil } \\
\text { society }\end{array}$ & $\begin{array}{c}\text { Exis- } \\
\text { tence } \\
\text { of } \\
\text { Local } \\
\text { Agenda } \\
21\end{array}$ & $\begin{array}{c}\text { Exis- } \\
\text { tence } \\
\text { of } \\
\text { Local } \\
\text { Agenda } \\
21 \\
\text { Forum }\end{array}$ \\
\hline Barra do Piraí & Yes & Yes & Yes & Yes & Monthly & Yes & Yes & Yes & Irregularly & Yes & No & - \\
\hline Barra Mansa & No & No & Yes & Yes & Monthly & Yes & Yes & No & - & - & Yes & Yes \\
\hline Itatiaia & Yes & Yes & Yes & Yes & Monthly & Yes & Yes & No & - & - & Yes & No \\
\hline Pinheiral & No & No & Yes & Yes & Monthly & Yes & No & - & - & - & No & - \\
\hline Piraí & Yes & No & Yes & Yes & Monthly & Yes & No & - & - & - & No & - \\
\hline Porto Real & Yes & No & Yes & Yes & Monthly & Yes & Yes & No & - & - & No & - \\
\hline Quatis & No & No & Yes & Yes & Monthly & Yes & Yes & No & - & - & No & - \\
\hline Resende & Yes & Yes & Yes & Yes & Bi-weekly & Yes & Yes & Yes & Irregularly & Yes & Yes & Yes \\
\hline Rio Claro & Yes & No & Yes & Yes & Monthly & Yes & No & - & - & - & Yes & Yes \\
\hline Rio das Flores & Yes & No & Yes & Yes & Monthly & Yes & No & - & - & - & Yes & No \\
\hline Valença & No & No & Yes & Yes & Monthly & Yes & Yes & Yes & Monthly & No & Yes & Yes \\
\hline Volta Redonda & No & No & Yes & Yes & Monthly & No & Yes & Yes & Monthly & Yes & Yes & Yes \\
\hline
\end{tabular}

Sources: Brazilian Institute of Geography and Statistics 14,15 .

networks for services supply and access at different levels of complexity 25. Although such initiatives are important, they are still disconnected and sector-limited, taking a compartmentalized approach to the environment (water, for example) and health as a synonym for "healthcare".

\section{Final remarks}

Public Health faces a huge challenge in building systems of sustainability indicators that integrate the environmental and human well-being dimensions, related primarily to the very limits of the available data (although the latter are useful, they have been produced with sector-limited objectives, namely social, environmental, economic, and health-related). Such limitations are even greater in the environmental sector because: (1) environmental statistics are recent in Brazil and are still not available at the municipal level, the way health data are found in the DATASUS database; (2) there are still numerous uncertainties about the changes in the structure and dynamics of ecosystems and their interaction with the socio-environmental system, resulting in diseases, health problems, and restraints on human wellbeing.

Important limitations include insufficient dialogue between the environmental and health sectors for jointly building human well-being indicators. When the environmental indicators do incorporate health aspects, they are generally limited to child morbidity and mortality and life expectancy at birth. When the health indicators incorporate environmental aspects, they are limited to issues like water quality for human consumption and sanitation (basically access to the public sewage system and garbage collection), thus maintaining the environmental paradigm with the 19th century hygienist approach. Meanwhile, social and economic information is stilled treated in a fragmented way by both sectors.

Even considering these limitations, by combining a diverse set of data, indicators, and indices, it was possible to demonstrate how direct 
and indirect driving forces have degraded the ecosystem services, even while (paradoxically) the economy and population have grown, life expectancy has increased, and child mortality has decreased. The results indicate that this process may not be sustainable. While there have been improvements in some traditional indicators of health and well-being, there has also been clear degradation of the environment and ecosystem services. Since the 19th century, the successive economic cycles structured around short-term gains have decreased the options offered by ecosystems as services, thus making the well-being of present (and especially future) generations more vulnerable. This trend is not limited to the region analyzed here, but is part of a global process, posing one of the main challenges for Public Health in the $21^{\text {st }}$ century.

\section{Resumo}

A urbanização da população é uma tendência mundial e as atividades sócio-econômicas nestas áreas resultam em alterações que afetam o meio ambiente e o bem-estar humano para além de seus territórios, conectando áreas urbanas com não-urbanas, constituindo cidades-regióes. O objetivo deste artigo é, em perspectiva ecossistêmica, reunir um conjunto de informações sobre municípios integrantes da Região do Médio Paraíba, Estado do Rio de Janeiro, Brasil, de modo a indicar condições e tendências da sustentabilidade ambiental e do bem-estar. A estrutura conceitual adotada teve como referência a adotada no Millennium Ecosystem Assessment, identificando forças motrizes diretas e indiretas que afetam o bem-estar humano, sendo a saúde um componente do mesmo. Utilizou-se um conjunto de fontes de dados e informações sobre os municípios disponíveis e de acesso público agrupadas em condições sócio-econômicas, ambientais e de bemestar estrutural institucional para a sustentabilidade. Os indicadores utilizados apontam para um processo de degradação dos serviços dos ecossistemas que ainda não encontram barreiras suficientes na estrutura institucional vigente, potencializando restrições ao bemestar e ampliação dos impactos sócio-ambientais no médio e longo prazos.

Indicadores Ambientais; Indicadores de Saúde; Indicadores de Desenvolvimento Sustentável

\section{Contributors}

C. M. Freitas planned and organized the collecting, systematization and analysis of the available data and information, besides heading all the stages in drafting the article. G. E. Schütz and S. G. Oliveira participated in systematization and analysis of the data and information.

\section{Acknowledgements}

This article resulted from research financed by the Brazilian National Research Council (CNPq) (Universal Research Project, grant 481281/2004-5) and the Program to Support Strategic Research in Health/Water (PAPES-Água) under the Office of the Vice President for the Environment and Reference Services, Oswaldo Cruz Foundation. 


\section{References}

1. United Nations Environmental Program. Global environmental outlook 3. Data compendium - time series indicators for countries and aggregations [CD-ROM]. Geneva: United Nations Environmental Program; 2002.

2. Millennium Ecosystem Assessment. Ecosystem and human well-being - synthesis. http://www. millenniumassessment.org/ (accessed on 21/Jun/ 2005).

3. Ravetz J. City region 2020 - integrating planning for a sustainable environment. London: Earthscan Publications Ltd.; 2000.

4. Pickett STA, Burch Jr. W, Dalton SE, Foresman TW, Grove JM, Rowntree R. A conceptual framework for the study of human ecosystem in urban areas. Urban Ecosystem 1997; 1:185-99.

5. De Kruijf HAM, van Vuuren DP. Following sustainable development in relation to the North-South dialogue: ecosystem health and sustainable indicators. Ecotoxicol Environ Saf 1998; 40:4-14.

6. Bellen HM. Indicadores de sustentabilidade - uma análise comparativa. Rio de Janeiro: Editora FGV; 2005.

7. Borghesi S, Vercelli, A. Sustainable globalization. Ecol Econ 2003; 44:77-89.

8. Hancock T, Garret M. Beyond medicine - health challenges and strategies in the $21^{\text {st }}$ century. Futures 1995; 27:935-51.

9. Waltner-Toews D. The end of medicine: the beginning of health. Futures 2000; 32:655-67.

10. Morrow BH. Identifying and mapping community vulnerability. Disasters 1999; 23:1-18.

11. Freitas CM, Porto MFS. Saúde, ambiente e sustentabilidade. Rio de Janeiro: Editora Fiocruz; 2006.

12. Hales S, Butler C, Alistair W, Corvalan C. Health aspects of the Millennium Ecosystem Assessment. EcoHealth 2004; 1:124-8.

13. Fundação CIDE. Índice de qualidade dos municípios [CD-ROM]. Rio de Janeiro: Fundação CIDE; 2003.

14. Instituto Brasileiro de Geografia e Estatística. Perfil dos municípios brasileiros - gestão pública 2001 [CD-ROM]. Rio de Janeiro: Instituto Brasileiro de Geografia e Estatística; 2002.

15. Instituto Brasileiro de Geografia e Estatística. Perfil dos municípios brasileiros - meio ambiente 2002 [CD-ROM]. Rio de Janeiro: Instituto Brasileiro de Geografia e Estatística; 2005.
16. Campos A, Pochmann M, Amorin R, Silva R, organizadores. Atlas da exclusão social no Brasil - dinâmica e manifestação territorial. v. 2. São Paulo: Cortez Editora; 2003.

17. Fundação João Pinheiro. Atlas do desenvolvimento humano no Brasil. http://www.fjp.gov.br (accessed on 20/Nov/2005).

18. Miranda EE, Gomes EG, Guimarães M. Mapeamento e estimativa da área urbanizada do Brasil com base em imagens orbitais e modelos estatísticos. Campinas: Empresa Brasileira de Pesquisa Agropecuária. http://www.urbanizacao.cnpm.embrapa.br (accessed on 07/Apr/2006).

19. Instituto de Pesquisa e Planejamento Urbano e Regional, Universidade Federal do Rio de Janeiro/Federação de Órgãos para Assistência Social e Educacional. Mapa dos conflitos ambientais no Estado do Rio de Janeiro [CD-ROM]. Rio de Janeiro: Instituto de Pesquisa e Planejamento Urbano e Regional, Universidade Federal do Rio de Janeiro/Federação de Órgãos para Assistência Social e Educacional; 2004.

20. Kay JJ, Regier HA, Boyle M, Francis G. An ecosystem approach for sustainability: addressing the challenge of complexity. Futures 1999; 31:721-42.

21. Gruben A, Lopes PD, Johnson RMF. A bacia do Rio Paraíba do Sul, São Paulo, Rio de Janeiro e Minas Gerais, 2001 - Projeto Marca d'Água, relatórios preliminares. Brasília: Núcleo de Pesquisas em Políticas Públicas; 2002.

22. Pimm S, Jenkins C. Conservação da biodiversidade. Scientific American Brasil 2005; 41:58-65.

23. Minayo MCS. Inequality, violence, and ecology in Brazil. Cad Saúde Pública 1994; 10:241-50.

24. Rede Interagencial de Informações para a Saúde. Indicadores básicos para a saúde no Brasil - conceitos e aplicações. Brasília: Organização PanAmericana da Saúde; 2002.

25. Castro EMNV, Moreira RJ. Integração regional e iniciativas sustentáveis no Médio Paraíba do Sul RJ. Rio de Janeiro: Programa de Pós-graduação em Desenvolvimento, Agricultura e Sociedade, Universidade Federal Rural do Rio de Janeiro; 2002.

Submitted on 02/May/2006

Final version resubmitted on $06 / \mathrm{Feb} / 2007$

Approved on 08/Feb/2007 